\title{
Mechanism of radium-226 transfer from sediments and water to marine fishes
}

\author{
Boonsom Porntepkasemsan and Ahmad E. Nevissi \\ Office of Atomic Energy for Peace, Thanon Vibhavadi Rangsit, \\ Bangkhen, Bangkok-10900, Thailand and Laboratory of Radiation Ecology, WH-10, \\ University of Washington, Seattle, Washington 98195, USA
}

(Received January 31, 1990; Accepted June 5, 1990)

\begin{abstract}
A study was conducted in Puget Sound, Washington, USA, to evaluate the accumulation of radium-226 in benthic fishes. The radium content of whole fish ranged from 0.83 to $20.33 \mathrm{pCi} / \mathrm{kg}$ wet weight and the calcium content ranged from 114 to $259 \mathrm{mg} / \mathrm{g}$ ash. Basically, no consistent correlation was found between radium and calcium concentration in fish. The concentration factor for transfer of radium from seawater to benthic fish ranged from 8 to 184 which is much lower than the corresponding values for the pelagic fish.
\end{abstract}

\section{INTRODUCTION}

Radium isotopes and their ultimate precursors, uranium and thorium, occur naturally in virtually all types of rock, soil, sediment, and seawater. However, their radioactivity may vary with specific site and geological media. From the five naturally occurring radium isotopes, only Ra-226 is considered to be biologically most significant, though another isotope, Ra-228, should be studied owing to its rather long halflife of 5.7 years. For fish, its half-life is not short and the ratio of $\mathrm{Ra}-228 / \mathrm{Ra}-226$ is also interesting from the marine biogeochemical point of view. However, in this study, only radium226 , or simply "radium" was investigated in fish and will be discussed below.

\section{BACKGROUND INFORMATION}

In terrestrial environment, the transfer and fate of radium from uranium mine tailing and milling operations are important ecological concerns. Elevated levels of radium in vegetation, fish, and other biota living on or near tailing disposal sites have been reported by Wren et al.
(1987), Justyn et al. (1985), and Hesslein and Slavicek (1984). Although the biological half-life of radium in fish has not been measured experimentally, evidence from other species shows that the half-life may be quite long. For example, Jeffree and Simpson (1986) reported steady accumulation of radium in freshwater mussels over 56 days of the experimental period. The uptake was only inhibited by increased $\mathrm{Ca}$ and $\mathrm{Mg}$ water concentration. They also reported no significant loss of radium during 286 days depuration period indicating a very long biological half-life for this element in the mussel tissue.

In marine waters, dissolved radium is leached from sediments into the overlying water column, whereas particulate radium is the result of resuspension of bottom sediments or riverine input. Hence, radium may be transferred from sediment to biota via water, suspended particulate matter, or the marine food web. Measurements of radium in marine fishes and sediments have been reported by Joshi et al. (1984) and Bonotto et al. (1985) and the concentration factors of radium from sediment to benthic fish have been calculated by these authors. 
However, much higher concentration of radium has been reported in pelagic fish (Jenkins, 1969), than in the benthic fish. It should be noted that pelagic fish have no contact with sediment, whereas the benthic fish is in direct contact with sediments.

This paper presents the results of radium measurements in sediments and different fish species in Puget Sound, WA and discusses the routes of radium uptake in fish.

\section{Materials ANd Methods}

Fish samples, collected by otter trawl, included Dover sole (Microstomus pacificus); English sole (Parophrys vetulus); rex sole (Glyptocephalus zachirus); slender sole (Lyopsetta exilis); hake (Merluccius productus); and longnose skate (Raja rhina). The samples were weighed, measured, sexed, and sorted by species.

In the laboratory, the whole fish samples were dried at $80^{\circ} \mathrm{C}$ and then dry-ashed at $550^{\circ} \mathrm{C}$. The ash was dissolved in concentrated nitric acid with addition of hydrogen peroxide to oxidize the organic material. Barium-133 and barium carrier were added to the samples for chemical yield determination and co-precipitation. The radium was co-precipitated with barium sulfate, the precipitate was converted to carbonate, and dissolved in nitric acid. Radium was extracted from this solution into thenoyltrifluoroacetone, re-precipitated, stored for three weeks, and the filter was covered with $\mathrm{ZnS}$ phosphor paper and alpha counted for Ra-226 using a photomultiplier tube. Calcium was determined by

Table 1. Radium-226 content of whole fish, $\mathrm{pCi} / \mathrm{kg}$ wet $\mathrm{wt}$; calcium content of ashed fish, $\mathrm{mg} / \mathrm{g}$ ash; and the ratio of $\mathrm{Ra} / \mathrm{Ca}, \mathrm{pCi} / \mathrm{g}$, for the fish samples collected in Puget Sound

\begin{tabular}{|c|c|c|c|c|c|}
\hline Species & $\begin{array}{l}\text { Sample location, } \\
\text { Pt. Gardner }\end{array}$ & $\begin{array}{c}\mathrm{Ra}-226 \\
\mathrm{pCi} / \mathrm{kg} \text { wet wt }\end{array}$ & $\begin{array}{c}\mathrm{Ca} \\
\mathrm{mg} / \mathrm{g} \text { ash }\end{array}$ & $\begin{array}{l}\mathrm{Ra} / \mathrm{Ca} \\
\mathrm{pCi} / \mathrm{g}\end{array}$ & Sex \\
\hline English sole & Control site 1 & $5.5 \pm 1.2$ & 213.6 & 0.5 & F \\
\hline Slender sole & & $4.9 \pm 0.9$ & 259.3 & 0.6 & $\mathrm{~F}$ \\
\hline Slender sole & Control site 2 & $1.8 \pm 0.6$ & 182.8 & 0.3 & $\mathrm{M}$ \\
\hline Longnose skate & & $0.9 \pm 0.3$ & 131.6 & 0.3 & - \\
\hline Rex sole & Navy site rep 1 & $8.9 \pm 1.9$ & 194.3 & 0.6 & $\mathrm{~F}$ \\
\hline English sole & & $2.6 \pm 0.6$ & 197.3 & 0.4 & M \\
\hline Slender sole & & $2.4 \pm 0.6$ & 228.0 & 0.4 & $\mathrm{~F}$ \\
\hline Slender sole & Navy site rep 2 & $4.3 \pm 0.8$ & 237.4 & 0.6 & M \\
\hline Slender sole & & $3.6 \pm 0.7$ & 159.9 & 1.0 & $\mathrm{~F}$ \\
\hline English sole & Control site 1 & $1.4 \pm 0.5$ & 197.3 & 0.2 & M \\
\hline Dover sole & (Pt. Surdner) & $0.8 \pm 0.2$ & 219.6 & 0.3 & - \\
\hline English sole & Station E & $20.3 \pm 2.6$ & 207.8 & 1.5 & $\mathrm{~F}$ \\
\hline Slender sole & & $17.0 \pm 3.2$ & 124.0 & 0.6 & M \\
\hline Slender sole & & $15.9 \pm 3.1$ & 237.1 & 0.7 & F \\
\hline Hake & & $3.0 \pm 0.8$ & 124.0 & 0.8 & F \\
\hline Hake & Station 3 & $2.3 \pm 0.6$ & 114.1 & 0.8 & $\mathbf{F}$ \\
\hline Dover sole & Control OT & $4.0 \pm 0.6$ & 231.6 & 0.9 & M \\
\hline English sole & & $1.1 \pm 0.4$ & 203.3 & 0.3 & M \\
\hline Slender sole & & $1.1 \pm 0.4$ & 164.5 & 0.4 & $\mathrm{~F}$ \\
\hline English sole & Transect $710 \mathrm{~N}$ & $2.9 \pm 0.7$ & 215.6 & 0.4 & F \\
\hline Slender sole & Transect $100 \mathrm{M}$ & $0.9 \pm 0.3$ & 247.6 & 0.2 & $\mathrm{M}$ \\
\hline
\end{tabular}




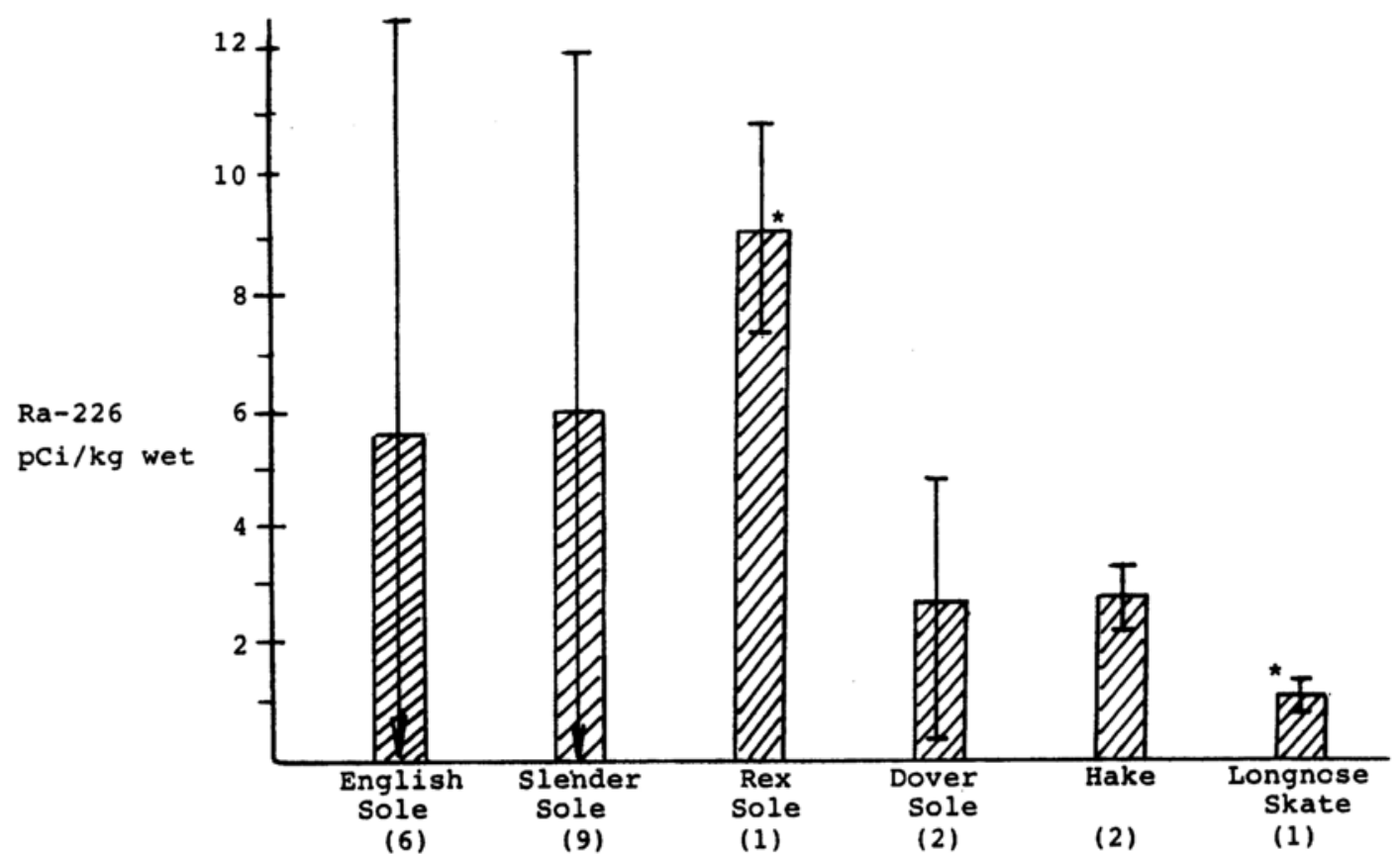

Fig. 1. Mean and the standard deviation of radium concentration in fish samples. Values in pCi/ $\mathrm{kg}$ wet wt. The numbers in ( ) represent the number of replicates of individual species. $\left({ }^{*}\right)=1$ S.D. of propagated counting error of a single sample.

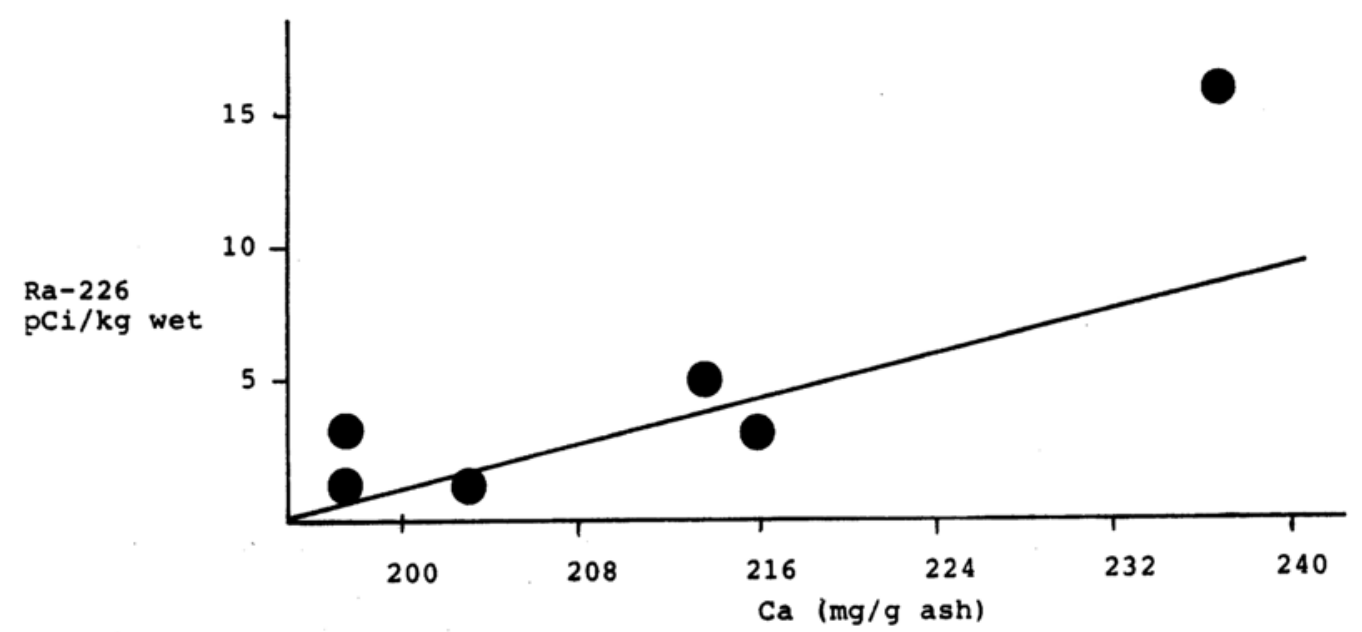

Fig. 2. Correlation between radium content, $\mathrm{pCi} / \mathrm{kg}$ wet wt., and the calcium concentration, $\mathrm{mg} / \mathrm{g}$ ash, in English sole. Correlation coefficient $=0.839$.

atomic absorption spectrophotometry in the diluted sample solution.

Sediment cores were collected at several locations using open barrel gravity corer (Nevissi et al., 1989). For Ra-226 and Ra-228 measure- ments, $50 \mathrm{~g}$ of dry sediment was pressed and sealed into a standard counting geometry and gamma activity counted by $\mathrm{Ge}(\mathrm{Li})$ detection system. 


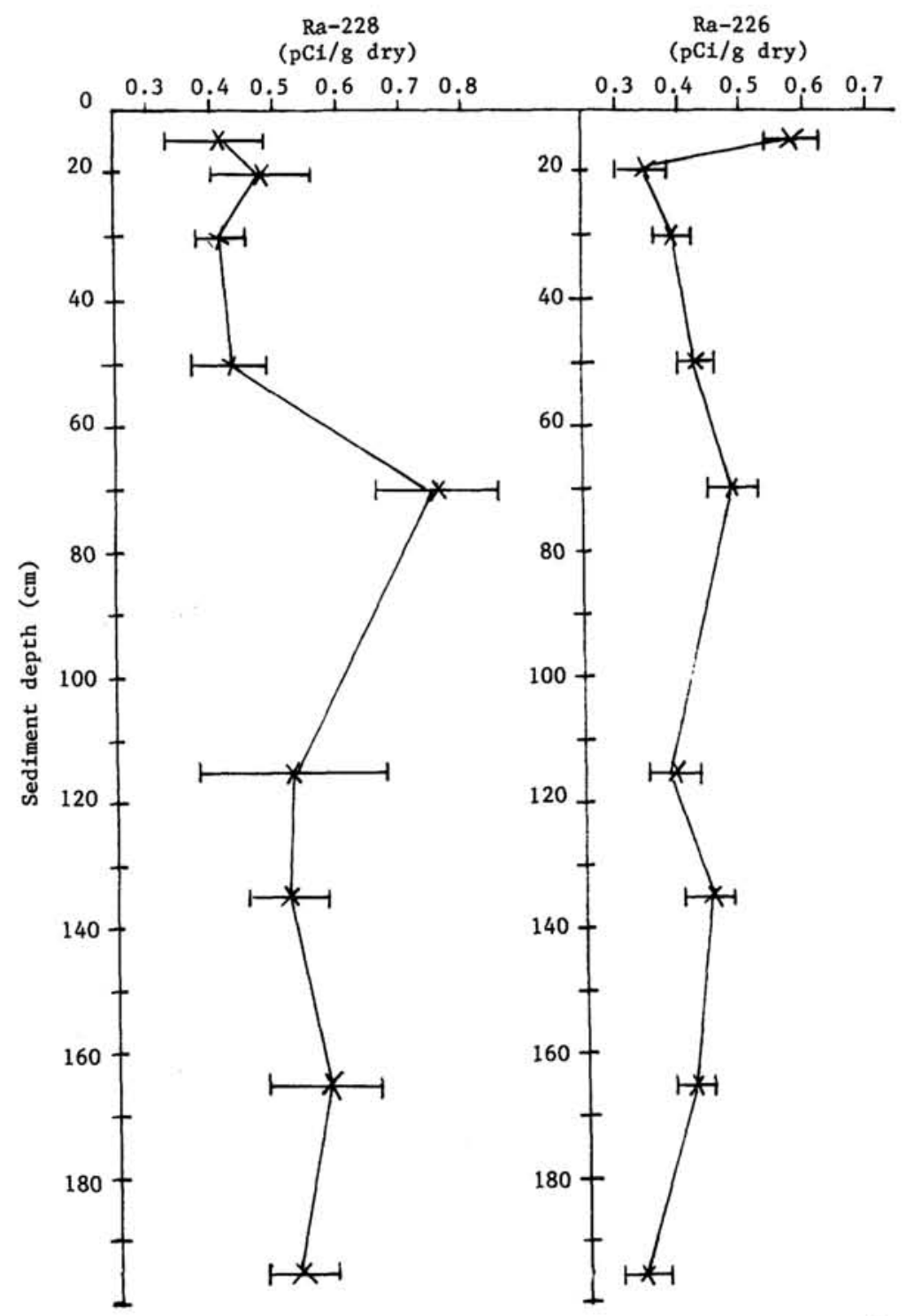

Fig. 3. Concentration of radium-228 and radium-226 in sediment core. Values in $p C i / g$ dry sediment $\pm 1 \sigma$ propagated counting error.

\section{Results AND Discussion}

The concentration of radium measured in 21 fish samples ranged from 0.833 to $20.328 \mathrm{pCi} / \mathrm{kg}$ wet wt. and calcium content ranged from 114.1 to $259.3 \mathrm{mg} \mathrm{Ca} / \mathrm{g}$ ash (Table 1). The highest radium activity was observed in rex sole, followed by slender sole and English sole (Fig. 1). No consistent differences between the radium content of male and female fish were observed (Table 1).
The metabolism of radium in animals and plants is similar to that of calcium. It accompanies the calcium through the food chain, and finally is deposited in the bone tissue. However, when a regression analysis of the radium content versus calcium concentration of all the fish samples was performed, no correlation was found. But when the data were analyzed by species, a correlation coefficient of 0.839 was found for the English sole (Fig. 2). This may suggest older fish having larger bones and higher 
calcium content tend to accumulate more radium than the smaller fish of the same species. However, the same regression analysis performed for slender sole showed no correlation between radium and calcium. For other species, the number of data points was too small to allow a rigorous statistical analysis. Overall, a consistent relation between radium and calcium was not obtained in this study.

The Ra-226 contents of sediment samples from deep areas of Puget Sound were within the range of the values reported for marine coastal areas, about $0.5 \mathrm{pCi} / \mathrm{g}$ dry (Schell and Nevissi, 1983). The levels of Ra-226 were almost constant in the sediment column (Fig. 3). A sediment Ra226 value of $0.43 \mathrm{pCi} / \mathrm{g}$ dry, corresponding to $142 \mathrm{pCi} / \mathrm{kg}$ of wet sediment, was used for calculations, $67 \%$ water content of surface sediments (Nevissi et al., 1989).

For comparision, the Ra-228 depth profile for the same sediment core is also shown in Fig. 3. However, since Ra-228 was not measured in fish samples, this isotope will not be discussed in the following.

Radium in the water column was not measured as part of this study and published values were used for calculations. Radium-226 profiles from northeast Pacific show typically low concentration in the surface waters which gradually increases with depth. The average surface concentration, $0-300 \mathrm{~m}$, ranges $6-10$ $\mathrm{dpm} / 100 \mathrm{~kg}$ which increases to $31-45 \mathrm{dpm} / 100$ $\mathrm{kg}$ at greater depths (Chung, 1976). In Puget Sound, due to relatively short residence time of water, the measured value is about $11 \mathrm{dpm} / 100$ $\mathrm{kg}$ (Smethie, 1979).

The radium content of Puget Sound fish is comparable to previously reported values. For example, Muth et al. (1960) reported radium values of $4.0 \mathrm{pCi} / \mathrm{kg}$ wet wt. in herring and 6.3 $\mathrm{pCi} / \mathrm{kg}$ wet wt. for haddock. A radium range of 1.4 to $3.2 \mathrm{pCi} / \mathrm{kg}$ wet wt. was reported for perch (Perca fluviatilis) by De Bortoli and Gaglione (1972). Radium values reported for Pacific salmon, chum (Oncorhynchus keta) and coho (O. kisutch), ranged from 2 to $50 \mathrm{pCi} / \mathrm{kg}$ wet wt. (Jenkins, 1969).
It should be noted that perch, herring, and salmon are pelagic fish that are usually distributed in the upper $300 \mathrm{~m}$ of water column containing the least amount of radium. In contrast, the benthic fish in this study, except hake, are in almost constant contact with the bottom sediments, the source of radium to the water column. However, the overall mean concentration of radium, calculated from the values reported by Jenkins (1969), for salmon is $26.4 \pm 20$ $\mathrm{pCi} / \mathrm{kg}$ wet wt., whereas the corresponding value for this study is $5.0 \pm 5.6 \mathrm{pCi} / \mathrm{kg}$ wet wt. Hence, the mean radium content of salmon, a pelagic fish, is 5 times higher than the radium content of benthic fish. For this reason, the bottom sediments are not considered as a direct source of radium to benthic or to pelagic fishes. The other possible sources of radium to fish are direct uptake from the water and/or through the food.

Direct uptake from water is possible because most teleosts (bony fish) drink large quantities of seawater. Since they have much lower salt concentration in body fluids than seawater, in order to keep the salt balance, the fish drink large quantities of seawater and produce only small quantities of urine. They lose water osmotically across the gills and salts through the feces. However, the different salts from the seawater are not retained in the body fluids in proportion to their abundance in the seawater (Royce, 1972). Hence, it is possible that through the osmoregulation process, radium is selectively concentrated in fish relative to seawater.

Previous investigations indicate that marine organisms, during normal growth, concentrate essential elements from seawater by factors which may vary from less than unity to $10^{6}$ (Hill, 1963). Although little is known on the transfer of radium through the marine food chain, it seems that this element is concentrated in plankton, the base of marine food web, relative to the seawater. It has been shown that certain diatoms, e.g., Rhizosolenia and Chaetoceras, markedly concentrate radium from seawater (Shannon and Cherry, 1971). Tests of siliceous plankton have been suggested as a major carrier 
for radium (Ku et al., 1970), and the correlation between radium and silicate in seawater has been reported (Ku and Lin, 1976). Also, it has been shown that non-siliceous plankton and mollusc shells concentrate radium relative to calcium by factors of less than 60 (Szabo, 1967). If the fish feed on plankton, as in the case of chum salmon, then the radium is transferred to a higher trophic level.

The magnitude of a radionuclide transfer from one compartment to the next, in this case from sediment or water to fish, is defined as the concentration factor, C.F.:

$$
\text { C.F. }=\frac{\mathrm{pCi} / \mathrm{kg} \text { wet wt. of fish }}{\mathrm{pCi} / \mathrm{kg} \text { water or wet sediment }}
$$

Using the above relation and referring to the data shown in Table 1 and others the concentration factor between water and fish, is calculated to be 8 to 184 and between fish and sediment to be 0.006 to 0.143 for this study. In contrast, reported concentration factors from ocean water to salmon ranged from 45 to 1200 (Jenkins, 1969). This may be due to the high metabolic rate in salmon as compared to the relatively sluggish bottom fish, even though the benthic fish are in an environment containing more radium than the pelagic fish.

Acknowledgments-This study was made possible by the International Atomic Energy Agency (IAEA) fellowship program.

\section{REFERENCES}

Bonotto, S. and Ortinsdd Bettencourt, A. (1985) Research program related to sea disposal of lowlevel radioactive waste. Waste Manage. Res. Abstr. 117.

Chung, Y. C. (1976) A deep Ra-226 maximum in the northeast Pacific. Earth Planet. Sci. Lett. 32, 249257.

De Bortoli, M. and Gaglione, P. (1972) Radium-226 in environmental materials and foods. Health Physics 22, 43-48.

Hesslein, R. H. and Slavicek, E. (1984) Geochemical pathways and biological uptake of radium in small Canadian shield lakes. Can. J. Aquat. Sci. 41, 459468.

Hill, M. N. (1963) The Sea. 81-83. Interscience
Publishers, New York.

Jeffree, R. A. and Simpson, R. D. (1986) An experimental study of the uptake and loss of Ra-226 by the tissue of the tropical freshwater mussel, Velesunio angasical (sowerby) under varying $\mathrm{Ca}$ and $\mathrm{Mg}$ water concentrations. Hydrobiologia 139, 59-80.

Jenkins, C. E. (1969) Radionuclide distribution in Pacific salmon. Health Physics 17, 507-512.

Joshi, L. U., Zingde, M. D. and Desai, B. N. (1984) Studies on $\mathrm{Ra}-226$ and $\mathrm{Pb}-210$ activities and the concentration factors of Ra-226 in the surface organic layers of the estuarine sediments of Mindola and Purna rivers in India. J. Radioanal.Chem. Articles 82, 369-377.

Justyn, J., Oliva, O., Pivnicka, K. and Svatora, M. (1985) Accumulation of natural radionuclides and growth of selected fish species in contaminated waters. Vestin. Cesk. Spol. Zool. 49, 253-266.

$\mathrm{Ku}, \mathrm{T}$. L. and Lin, M. C. (1976) Ra-226 distribution in the Antarctic Ocean. Earth Planet. Sci. Lett. 32, 236-248.

$\mathrm{Ku}$, T. L., Li, Y. H., Mathieu, G. G. and Wong, H. K. (1970) Radium in the Indian-Antarctic Ocean south of Australia. J. Geophys. Res. 75, 5286.

Muth, H., Rajewsky, B., Hantke J., and Aurand, H. (1960) The normal radium content and the Ra$226 /$ Ca ratio of various foods, drinking water, and different organs and tissues of the human body. Health Physics 2, 239-245.

Nevissi, A. E., Shott, G. J. and Crecelius, E. A. (1989) Comparison of two gravity coring devices for sedimentation rate measurement by $\mathrm{Pb}-210$ dating techniques. Hydrobiologia. 179, 261-269.

Royce, W. F. (1984) Introduction to the practice of fishery science. Academic Press. 428.

Schell, W. R. and Nevissi, A. E. (1983) Radionuclides at the Hudson Canyon disposal site. Waste in the Ocean, 3, Radioactive Waste and the Ocean, 183214, P. K. Park, Kester, D. R., Duedall, W. and Ketchum, B. H., eds., John Wiley \& Sons.

Shannon, L. V. and Cherry, R. D. (1971) Radium-226 in marine phytoplankton. Earth Planet. Sci. Lett. 11, 339.

Smethie, W. M. (1979) An investigation of vertical mixing rates in fjords using naturally occurring radon-222 and salinity as tracers. $\mathrm{PhD}$ Thesis, University of Washington Library.

Szabo, B. J. (1967) Radium content in plankton and seawater in the Bahamas. Geochim. Cosmochim. Acta. 30, 1321.

Wren, C. D., Cloutier, N. R., Lim, T. P. and Dave, N. K. (1987) Radium-226 concentrations in otter, (Luta canadensis), trapped near uranium tailings at Elliot Lake, Ont. Bull. Environ. Contam. Toxicol. 38, 209-212. 